University of Louisville

ThinkIR: The University of Louisville's Institutional Repository

Electronic Theses and Dissertations

$12-2013$

\title{
The marriage effect : an intergenerational analysis of marijuana desistance.
}

Rachel Coonce 1983-

University of Louisville

Follow this and additional works at: https://ir.library.louisville.edu/etd

\section{Recommended Citation}

Coonce, Rachel 1983-, "The marriage effect : an intergenerational analysis of marijuana desistance." (2013). Electronic Theses and Dissertations. Paper 274.

https://doi.org/10.18297/etd/274

This Master's Thesis is brought to you for free and open access by ThinkIR: The University of Louisville's Institutional Repository. It has been accepted for inclusion in Electronic Theses and Dissertations by an authorized administrator of ThinkIR: The University of Louisville's Institutional Repository. This title appears here courtesy of the author, who has retained all other copyrights. For more information, please contact thinkir@louisville.edu. 
THE MARRIAGE EFFECT: AN INTERGENERATIONAL ANALYSIS OF MARIJUANA DESISTANCE

\author{
By \\ Rachel Coonce \\ B.A., Centre College, 2006
}

\begin{abstract}
A Thesis
Submitted to the Faculty of the

College of Arts and Sciences of the University of Louisville In Partial Fulfillment of the Requirements

for the Degree of
\end{abstract}

Master of Arts

Department of Sociology
University of Louisville
Louisville, Kentucky

December 2013 

THE MARRIAGE EFFECT: AN INTERGENERATIONAL ANALYSIS OF MARIJUANA DESISTANCE

\author{
By \\ Rachel Coonce \\ B.A., Centre College, 2006
}

A Thesis Approved on

November 26, 2013

by the following Thesis Committee:

Ryan Schroeder, Thesis Director

Mark Austin

Viviana Andreescu 


\section{ACKNOWLEDGEMENTS}

I would like to thank my committee chair, Dr. Ryan Schroeder for sticking with me through two datasets and too many years. I would also like to thank the other members of my committee, Dr. Viviana Andreescu and Dr. Mark Austin for their guidance along the way. Also, many thanks to my parents, family, and friends for their patience, encouragement, and belief that I would finish this project when I was tempted to give up. 


\section{ABSTRACT \\ THE MARRIAGE EFFECT: AN INTERGENERATIONAL ANALYSIS OF MARIJUANA DESISTANCE \\ Rachel Coonce}

November 26, 2013

This thesis takes a gendered look at the criminological age-graded theory of informal social control, which posits that social bonds are strongly influential in curbing crime and deviance over the course of an individual's life. However, the theory was based on an all-male sample and is therefore not as applicable to women. It is likely that social bonds for men and women have evolved differently over the course of the last century and it is therefore the goal of this study to analyze how these changes are operating within this informal social control theory. Specifically, this paper analyzes marriage and its role in desistance from marijuana use. To study change over time, two generations of women were compared using two longitudinal studies. It was hypothesized that as the ideas and importance of marriage have evolved over time, marriage would become a weaker predictor of desistance for females in the second generation. However, as the findings indicate here, marriage remained significantly influential in desistance from marijuana use for both generations. 


\section{TABLE OF CONTENTS}

ACKNOWLEDGEMENTS.




\section{INTRODUCTION}

Sociological and criminological research has evolved recently with the emergence of age-graded life-course theory, a theory that allows researchers to consider the transmittance of values and lifestyles over several generations. Instead of focusing on what causes isolated individuals to commit acts of deviance, this theory focuses on the changing environments, such as the family or workplace, that surround an individual over time. The theory takes into account the pressures that might cause a previously deviant or criminal individual to stop committing crimes and to come in line with the rest of society or to continue on against certain standards, and how that behavior influences the actions of significant others.

Culled from years of previous works of longitudinal criminological and sociological research, Robert Sampson and John Laub (1993) formed the age-graded theory of informal social control, more commonly known as the life course theory of criminology, stating that social bonds, such as marriage, were strongly influential in curbing crime and deviance. However, due to sample limitations, the theory was based on an all-male sample of individuals. While their theory is innovative, given the differing experiences of males and females in terms of marriage and employment over the course of the last century, their findings might not be as applicable to women, considering the various women-centered movements surrounding these very issues over the last century. Ideas of marriage, motherhood, and female employment have changed 
significantly since the 1940's when the data used by Sampson and Laub was collected (Parson, 1942; Glueck and Glueck, 1950; Stacey, 1998; Bengtson, Biblarz and Roberts, 2002; Kreider and Simmons, 2003).

Therefore, the goal of this study is to determine the degree to which the theory of age-graded informal social control applies to women today and over the course of time. Such a study will require a look at macro-level societal changes in attitudes and behaviors concerning women, as well as micro-level attitudes and values passed on through intergenerational contact. My proposition here is to utilize the National Longitudinal Survey of Youth (1979) in conjunction with the National Longitudinal Survey of Youth Children and Young Adults samples to assess the role of marriage on marijuana desistance across two generations of women. The National Longitudinal Survey of Youth 1979, or NLSY79, was intended to be representative of United States residents who were born between the years 1957 and 1964 and to trace the life-course experiences of these individuals as they navigate young adulthood. The study was conducted annually from 1979 to 1994 and then biennially thereafter. The Children and Young Adults sample is a separate study analyzing the children of the women from the 1979 study and includes a young adult section, begun in 1994, that will allow comparisons of sets of parents and children at the same stage of life, but during different historical periods. These two data sets allow for analysis of the effects of social change on the transmission of values, resources, and behaviors. 


\section{LITERATURE REVIEW CHANGE OVER THE LIFE-COURSE}

In order to better position and understand micro level changes within a larger context, it is relevant to include an explanation of the life-course perspective. Sociologist Glen H. Elder (1985) was one of the earliest to realize the need to analyze an individual's behavior in connection to the historical and socioeconomic context in which the individual is positioned at any given time. He subsequently introduced the concepts of 'life trajectories,' 'transitions,' and 'turning points' in the evolution of an individual's behavior.

Trajectories are defined as diverse paths that people follow as they progress through life. Interconnected trajectories describe a process in which events in one's life affect both one's own trajectory and the trajectories of others. Incarceration, for example, affects not only the life trajectory of the one who is incarcerated but also his or her spouse, children and other family members. The life trajectories of everyone involved are interconnected. Life-course events embedded within trajectories are called turning points or transitions and may alter the trajectories of individuals. Examples of these turning points are specific events such as divorce, marriage, and having a child. A person's value system or behavior may be altered by such events, thus changing the course of his or her life altogether (Elder, 1985; Levinson, 2002; Sampson and Laub, 1993; Laub, Nagin and Sampson 1998). Specifically, Elder introduces "age-graded 
transitions," or those events that usually occur within a certain age-frame for an individual, such as marriage, childbirth, acquisition of a first job, or retirement. These age-graded transitions are embedded within the institutions of any given society and are thus subject to historical change (Elder, 1975). The average age of first marriage, for example, is subject to historical variance. Within the life-course approach, then, the intergenerational transmission of social patterns is of prime importance in establishing one's trajectory. Likewise, the effects of macro-level events on individual life stories are just as important in terms of both trajectory and transitions (Elder, 1985, 1998).

When applying theories of change over the life-course to crime and deviance specifically, I also thought it relevant here to look at the premises of social control theory and its basic assumption: that delinquent, or more broadly, criminal acts result when an individual's bond to society is weak or nonexistent (Hirschi, 1969). It will be important to define what is meant by a 'bond' to society. However, first it is also relevant to know how social control theory differs in the most fundamental criminological question: "What causes an individual to commit a criminal act?" Control theory, in fact, reverses the question. Instead of "why do they do it?" control theorists ask, "why don’t we do it?" (Hirschi, 1969). What needs explaining is not why an individual commits a crime but why an individual would refrain from committing a crime when in a position to do so? In terms of bonds to society, Travis Hirschi defined four kinds of bonds of which one or any combination of the four can be working on the individual to prevent him or her from actually carrying out the impulsive criminal act. The four: 'Attachment,' 'Commitment,' 'Involvement,' and 'Belief,' all revolve around the idea of an individual's connection to society. Attachment can essentially be defined as the 'internalization of 
norms..." to conventional society (Hirschi, 1969:18) It is the extent to which stigma and social opinion regarding anti-social acts play a role in one's thought processes, and ultimately, one's behavior. The more attached an individual is to the conventional social pressures, the less likely he is to commit a crime.

Hirschi also theorizes on the role of one's commitment to society or the fear of the consequences of disobeying the rules. "The individual invests time, energy, himself, in a certain line of activity — say, getting an education, building up a business... When or whenever he considers deviant behavior, he must consider the costs of this deviant behavior, the risk he runs of losing the investment he has made in conventional behavior" (Hirschi, 1969). This idea of commitment could be extended, as well, to commitment to a significant other; commitment to a marriage or relationship.

Involvement is the sense that one is too busy in the participation of conventional activities to find the time, energy, or desire to engage in deviant behavior. And the last of Hirschi's four is belief. Here he acknowledges that there is variation in the extent to which people believe the rules apply to them. There is a common value system in any society and yet, individuals will differ in the meanings that they attach to how this system applies to them. The less a person believes she should obey the rules for whatever reason, the more likely she is to violate them.

I have chosen to begin with control theory in this analysis because of its relevance to changing norms and attitudes and because of the central role of social control in the life course theory. How strongly are people attached to informal social institutions of control, such as traditional gender roles? And if these institutions are changing, how do these changes affect deviant acts? Could it be that as traditional behavior and beliefs 
evolve, individuals also feel less inclined to conform to norms surrounding antisocial behavior?

In order to study changes in informal social institutions, I find it most appropriate to take a longitudinal approach, both historically and in individual lives. From a historical perspective, collective changes in attitudes and behaviors surrounding important social institutions are instructive in the analysis of what individuals are pressured by society to value and conform to. For example, gender relations and attitudes about appropriate female behavior have changed significantly over the past century. As sociologist Talcott Parsons acknowledged as late as 1942, “the woman's fundamental status is that of her husband's wife, the mother of his children, and traditionally the person responsible for a complex of activities in connection with the management of the household, care of children, etc.” (Parsons, 1942: 609). Since then, women have gained more autonomy in connection with their relationships and marriages and have expanded their employment opportunities outside the home. By studying this evolution of collective behavior over time, we can analyze how certain bonds and attachments to society have changed and what the changes mean for women's conforming or deviant behavior.

It is also relevant to take a longitudinal approach in individual lives to determine what social forces may have been at work in one's life and when these forces dictated behavior and changes in behavior over time. Much as bonds and attachments evolve on the collective, societal level, so too do an individual's attachments and values develop over the course of one's life, so it is important to take into account several periods in one's life when analyzing behavior and specifically deviant behavior. 
Hirschi would later downplay this longitudinal study of lives in his control theory paradigm, emphasizing instead the early years of an individual's life and effective child rearing practices in the development of self-control. He would argue in the self-control theory of crime formulated with Gottfredson that one's self-control is a stable phenomenon, shaped largely by one's family and upbringing and once established is hard to modify in time (Gottfredson and Hirschi, 1990). However, it seems apparent that some individuals do modify their behavior over time, and Gottfredson and Hirschi struggle in explaining how individuals reshape their behavior and their lives in adulthood. Critics of this approach note that it makes behavior appear too static and ignores important variables in an individual's criminal career such as onset of behavior, career length, continuity, escalation, versatility, and desistance (Farrington, 1986; Blumstein et al., 1988)

\section{AGE-GRADED THEORY OF SOCIAL CONTROL}

In the early 1990's, the Harvard researchers Robert Sampson and John Laub found some unorganized cartons of data in the basement of the Harvard Law School Library. The data they found there had been compiled by the married researchers Eleanor and Sheldon Glueck in the 1930's and 1940's and was later used to publish their book, Unraveling Juvenile Delinquency. This lost information made up part of some of the first analyses of a sociological basis for crime causation. They themselves extolled the need for an eclectic approach to the study of crime causation not based solely on biological factors (Glueck and Glueck, 1950). The Gluecks compiled a sample of 500 
delinquent and 500 nondelinquent boys and controlled for age, general intelligence, national origin, and residence in underprivileged neighborhoods in Boston. They collected a vast amount of information through observation, interviews with parents and teachers, and even physical measurements. What they discovered were some notable sociological findings. For example, they found that a third of the delinquents as compared to only one-seventh of non-delinquents had resided for less than a year at their present address, the sanitary facilities in the homes of the delinquents were less adequate than those in the homes of the non-delinquents, and delinquent households were more crowded and less clean than those of the non-delinquents. Overall, economic condition of the family, sources of family income, average weekly income of the family per person, number of breadwinners, parental makeup of the home, whether the boy was living with his own mother and father, and the marital status of his parents were all significant in the outcome of the boy's behavior.

One of the important values of this data set and sociological methodology was that it was longitudinal in nature. The Gluecks had followed the boys throughout their lives with interviews every few years, so that when Sampson and Laub found this data, they could clearly see the progression that each individual life had taken. In this way, the researchers could see not only the sociological factors surrounding the onset of delinquency and crime, but also whether or not the boys who had begun a life of crime at a young age refrained from such behavior later in life and the factors surrounding such desistance. This ability to see the outcomes of the entire lives of individual delinquents and nondelinquents allowed Sampson and Laub to form their own theory: the age-graded theory of informal social control. Notably, this theory is rooted firmly in Hirschi's 
control theory. As Sampson and Laub admit, "Our general organizing principle is that the probability of deviance increases when an individual's bond to society is weak or broken" (Sampson and Laub, 1994: 18). Their focus is the formation of social bonds over the course of one's entire life and how as these bonds change, behavior, in turn, changes.

It is important to note that both the Gluecks and Sampson and Laub underscored the importance of the family as an informal institution of control with large effects on delinquent behavior in young boys. In fact, Sampson and Laub found that of the total effect of all structural background factors on delinquency, 73 percent is mediated by family process. Specifically the variables 'discipline', 'supervision' and 'attachment to the family' were strong indicators of behavior in childhood.

But Sampson and Laub's concern was more focused on the continuity and change in criminal behavior over time. As mentioned earlier, Gottfredson and Hirschi's theory emphasized that the attribute of self-control develops early in life, and once established, it is difficult to modify. In other words, there is an attribute present in some individuals that underlies certain behaviors. These behaviors are not necessarily criminal, but may be analogous to crime: numerous traffic accidents, smoking, sexual promiscuity, marital conflict, job instability, etc... These behaviors, like crime, are hypothesized to result from a common attribute, which is the lack of self-control.

Sampson and Laub move away from this 'inherent trait' idea and highlight instead the influence of social institutions when explaining change in behavior over the lifecourse, which is difficult to explain by an inherent lack of self-control. On the other hand, they contend "according to our thesis, childhood pathways to crime and 
conformity are significantly modified over the life-course by adult social bonds" (Sampson and Laub, 1993). It is not time or a randomly improved level of self-control that dictates desistance from criminal behavior, but rather the quality of social bonds that an individual forms with informal institutions over time. In this case, a positive quality of marriage, job stability, and social capital in general will directly result in less criminal behavior. What they find is that, similar to Elder (1998), social ties embedded in adult transitions explain variations in crime unaccounted for by childhood propensities, thus weakening the theory that behavior is generally static once developed in childhood (Sampson and Laub, 1993).

\section{MARRIAGE AND DESISTANCE}

Sampson and Laub found marriage to be a significant turning point in a man's life and his pattern of criminal behavior. They found marriage to be a major life event that significantly supports desistance from crime and this idea is backed up by a large amount

of research (Warr, 1998; Horney, Osgood, and Marshall, 1995; Li and MacKenzie 2003; Blokland and Nieuwbeerta, 2005). However, there has been some discussion about how exactly marriage functions in the process of desistance. Some researchers contend that it is the quality of marriage, or the strength of attachments and bonds between spouses that has the most effect (Laub, Nagin, and Sampson, 1998; Maume et al. 2005). Mark Warr contends that marriage creates a change in environment; men will associate with different types of people once they become married thus reducing exposure to deviant peer influences (Warr, 1998). Similarly, some have theorized that marriage fundamentally changes social networks and functions as a process of control through these new, usually 
more-conforming, networks (Giordano, Cernkovich and Holland, 2003; Osgood et al. 1996). Additionally, having children is thought to play a role in desistance and the presence of children has been examined accordingly (Giordano, Cernkovich, and Rudolph 2002; Uggen and Kruttschnitt, 1998). However, despite debate in the exact mechanisms in play with the marriage effect, it is broadly accepted that marriage has a positive effect for men in desistance from deviant behavior.

\section{DRUG AND ALCOHOL USE AS A MEASURE OF DEVIANCE}

Many sociological and criminological studies that involve an analysis of drug or alcohol use position this use as a precursor or predictor of more serious criminal offending. And most studies have confirmed a strong connection between substance use and criminal activity (Bennett, Holloway and Farrington, 2008; Nurco, Kinlock and Hanlon, 1991; Newcomb, Galaif and Carmona, 2001; Menard, Mihalic, and Huizinga, 2001). But regardless of the interplay of substance use and other types of criminal activity, substance use by itself, especially illegal substance use, can be categorized as a break from social norms. This is especially true with the heightened criminalization and harsher punishments for drug use brought on by the policies in the relatively recent 'War on Drugs.' Five times as many individuals are incarcerated now as in 1972 and this is thought largely to be a result of non-violent, drug-related arrests (Moore and Elkavich, 2008). Specifically, possession of marijuana constitutes the largest single arrest offense category, comprising almost half of all drug-related arrests (Nguyen and Reuter, 2012).

Yet even beyond the criminal justice system, arrests, and incarceration for drug-use, there have been several works that maintain that those who engage in frequent 
heavy drinking and all illegal drug-use are considered deviant, whether detained or not. (Anderson 1978; Nielsen, 1999). And social control deviancy literature has focused on the effects of binge drinking and substance abuse and the life occurrences or transition points that cause an individual to "age out" of such behavior. (Sampson and Laub 1993; Osgood et al. 1996; Chen and Kandel 1995; Labouvie 1996). Much has been documented as well about the protective effect that marriage and strong relationships play on desistance from heavy alcohol and drug use. This falls into informal social control models that document successful transitions into adulthood, socially conforming conduct and abstaining from substance misuse (Jessor et al., 1991; Maume et al, 2005; RhuleLouie and McMahon, 2007; Duncan et al, 2006).

Since desistance from heavy alcohol and drug-use has been shown to be positively responsive to marriage and strong romantic relationships, using the National Longitudinal Survey of Youth series, the current study assesses the relationship between substance use and a change in marital status. In this particular study, and based on the prevailing literature, I will situate marijuana-use as a measure of deviancy in this study.

\section{GENDER AND DEVIANCY}

Unfortunately, due to Sampson and Laub's reliance on the Gluecks' sample of delinquent males, females are not represented in the data upon which their theory is originally based. The Glueck sample was only able to track males, and therefore the generalizations made from these findings cannot be specified for female delinquency. Sampson and Laub were unable to test their numerous social variables along gendered lines. However, since the theory so closely deals with marriage and adult social bonds, it 
seems highly relevant to take a gendered approach, considering women and men arguably have had differing marital experiences, particularly on the societal level, over the course of history.

What I tried to take into account ultimately when examining a gendered difference in deviance based on social controls, were the social institutions themselves, how these institutions have changed over time, and whether the changes are having a measurable effect on female behavior generally. Many feminist researchers in the 1970's saw a clear increase in female criminality and deviance and tried to find a cause behind the pattern. The works of researchers Freda Adler and Rita James Simon are key to understanding the prevailing assumptions surrounding women, social institutions, and crime in this time period. Adler's liberation theory of female criminality is based on the idea that the success of the women's liberation movement is the primary cause of rising female crime rates. In Sisters in Crime: The rise of the New Female Criminal, Adler argues that the feminist movement is completely changing the way that women relate to the world. This is obvious not simply from a deviance standpoint, but from a rising female suicide rate, higher rates of mental illness, female-initiated divorces, and family desertions. New changes in the female perspective are not the result of a few women rallying around an organized movement, but rather an all-pervasive consciousness. And as a result of this consciousness, Adler notes, "for better or worse, women have lost many of the restraints which kept them within the law" (Adler, 1975). As proof, she cites the Uniform Crime Report dating from 1960 to 1972, which shows the arrest rate of females rising three times faster than the arrest rate of males over this time period (1975: 16). 
In Adler's theory, deviancy is a matter of opportunity, and traditionally women moved within very limited social confines. Therefore, opportunities and expectations for female criminal activity were few. However, a clear pattern is emerging in which as egalitarian forces increase, so too will the female crime rate. For younger women, the fluidity of gender roles often makes an anomic contribution to female deviance by weakening the community and familial structures, which have historically protected and restrained them. Similarly, urbanization, mobilization, and the rise in the divorce rate has given females great freedoms and opportunities in terms of choices, work and families, but also great freedoms and opportunities in terms of exposure to illegal and deviant activity. Adler specifically addresses the increase in female drug use by stating, "The closer we look at women who are making their way in a man's world, the more they look like men in their profile of... criminal deviancies and their addictive patterns (1975:132). Adler makes note of certain historical markers: World War II, the advance of civil liberties of the 1960 's, improving technology, and general medical advances as points through American history in which women's lives and roles changed dramatically. And the psychological changes wrought by all this societal transformation shifted female roles away from the traditional emphasis on "children, kitchen, and church" and towards more conventionally masculine pursuits. Consequently, as women's social status approaches that of men's, so does the frequency and type of their criminal activity (Adler, 1975).

In the same year that Adler published her work in Sisters in Crime, Rita James Simon put forth a similar view in Women and Crime. Her main hypothesis was that an increased participation in the labor force provides women with more opportunities for 
committing certain types of crimes, such as white-collar crimes. This was a matter mostly of opportunity; that expanding educational and occupational roles will increase the rate of involvement in crimes. After analyzing statistics from the Uniform Crime Reports of the mid-1960's to 1970, Simon finds a noticeable change in larceny and drunkenness, both of which have decreased while female narcotics use has increased. Simon acknowledges here that some of these statistical changes can be attributed to changes in the attitudes and the behavior of the police rather than a change simply in the propensities of women to engage in crime. However, because the rates of female arrests have varied by the nature of the offense, it is a strong indication that a change in police behavior cannot account for all of the shifts.

Feminist theory on female crime continued to evolve as the effects of the women's rights movement began to become apparent in time, allowing for a more nuanced look at the topic. In the late 1970's, Peggy Giordano responded to Adler and Simon's proposals by indicating that it is an oversimplification to claim such a clear and direct connection between female 'liberation' and direct involvement in crimes. This is especially true in finding a causal connection in any attitudinal changes related with the movement (Giordano, 1978). Giordano acknowledges the importance of control theory, however, when analyzing female crime and delinquency and she seems to agree somewhat with Adler and Simon in that the relaxing of tight constraints on females creates many more situations for females in which crime and delinquency may occur, and importantly, this would help explain increases in behavior such as excessive drinking and drug use where situational factors play a strong role. However, the crucial difference that feminist scholars began to find was not any kind of ideological liberation so much as 
the importance of a female's primary peer group. Giordano found a correlation between the extent of deviance approval for female friends and participation in delinquency (Giordano, 1978).

In a study completed in 1979 with Stephen Cernkovich, Giordano acknowledges finding that more delinquent girls considered marriage and children less important, but it is far from clear that liberation from traditional social constraints had anything to do with their attitudes at all. Their argument concludes with the idea that it may be that more open attitudes and a sense of liberation follow delinquent experiences, rather than vice versa (Giordano and Cernkovich, 1979). However, this study has a weakness in terms of studying marriage and 'transition points' through life as it studies the attitudes and behaviors of juvenile girls as opposed to adult women, making it somewhat weaker in measuring certain aspects of control theory. Giordano and Cernkovich do ask relevant questions, however, of the liberation theory of female crime and through their work come to the conclusion that arguments that stress the women's liberation movement are based on incomplete data and a priori assumptions (Cernkovich and Giordano, 2008).

Some limitations were found in Simon and Adler's contentions by a series of studies done using statistics from the 1960's and 1970's. The critique of Adler and Simon's 'emancipation theory' of female crime centered around the notion that it was simplified into an 'add women and stir' hypothesis; that women would behave exactly the way men would given the same opportunities. By studying sex differences in arrest rates over time, several studies (Steffensmeier, 1980; Chesney-Lind, 1989; Weis, 1976) have argued that it is actually changes in arrest patterns, rather than changes in actual female behavior and attitudes, that make the arrest of women more likely. It is clear that 
more women are being arrested since the 1950's, but it is far from clear that they are actually committing more crimes (Chesney-Lind, 1989). What seems to have changed are law enforcement practices, market consumption trends, and the worsening economic position of many females in the U.S. (Steffensmeier, 1980; Chesney-Lind, 1989). These researchers would continue to bring doubt to the idea that there was some kind of upswing in female criminality. For them, due to the 'emancipation theory,' the 1980's brought a kind of societal panic in which as Meda Chesney-Lind notes, "stories about the failure to get husbands, get pregnant, or properly bond with their children were suddenly everywhere." (Chesney-Lind, 2006:10) and that the increased female arrest rate was simply owing to a political backlash on this kind of societal panic as well as to the new policy of the War on Drugs which fueled mass imprisonment. Fortunately for my purposes here, this study will not rely on arrests or rates of imprisonment as measurements of deviancy but rather on self-acknowledged drug abuse patterns. Therefore, these confounding effects of police bias and societal panic should be minimized and internalized attitudes and their consequent behaviors should become clearer.

While Sampson and Laub's life-course theory is mostly based on males' experiences, it is also somewhat silent to changes in social dynamics both in societal roles and attitudes about these roles. The changing definitions of certain social institutions may play a significant role in informal social control systems. In turn, these altered informal social control mechanisms may have a changed impact on individual behavior in terms of Hirshchi's attachment, commitment, involvement and belief. For example, Sampson and Laub found that the quality of one's marriage serves as an adult 
social bond, which plays an influential role on crime and conformity in time. In fact, they state definitively that, "The major turning points in the life-course for the men who refrained from crime and deviance in adulthood were good marriages and stable employment" (Laub and Sampson, 2001:20). However, since the 1940's when the Glueck data was assembled, the definition and importance of some of these important social variables has changed. And, as previously shown, due to differing experiences, social movements, and role changes, there may be a gender difference in the definition and importance of these variables as well.

First, it is important to note how marriage as an institution has changed significantly in the past sixty years. Divorce has become more common since the Glueck's published their findings as the number of divorced people in the population more than quadrupled from 4.3 million in 1970 to 18.3 million in 1996 . In 1970, this number represented 3 percent of the population ages 18 and older. By 1996, this number represented 10 percent of the population ages 18 and older (Saluter and Lagaila, 1998). Also tellingly, in 1950 , the divorce rate was 2.6 people divorced for every 1,000 in the total population. By 1970, this was 3.5 people, 1980: 5.2, 1990: 4.7, and 2000: 4.2. This does not seem like a huge discrepancy until the percent change in those never married, which has increased significantly for those ages $15-24$, is taken into account (Kreider and Simmons, 2003; Stacey, 1998).

Also, the rates of cohabitation have greatly increased. In 1960, 439,000 couples were living together without being married. By 2000, this number had reached 5.5 million couples (Kreider and Simmons, 2003). Several works have demonstrated that cohabitation is one process in weakening the social bond that marriage creates. In 
general, this 'deinstitution' of marriage changes social norms that define behavior in social institutions, and generally, cohabiters report poorer relationship quality than those who are married (Cherlin, 2004; Brown and Booth, 1996). As seen here, the landscape of marriage as an institution has changed over the course of the $20^{\text {th }}$ and the beginning of the $21^{\text {st }}$ centuries in terms of higher rates of divorce, fewer marriages, more 'later-in-life' marriages, and higher rates of cohabitation.

Despite decades of changes in a number of areas, marriage seems to be the social institution that Sampson and Laub focus on the most. Based on Sampson and Laub's theorizing, the current study will analyze how marriage, and changing attitudes about marriage, may affect women and how these changes apply in a life-course paradigm. For this reason, it is my goal here to try to compare how marriage affects females in different generations in terms of deviancy.

Therefore, in light of the apparent role and attitude changes in female criminality and deviance over time, I hypothesize that as a result of macro level changes and growing equality between spouses, the effect of a marital bond on the desistance process will become weaker for women across subsequent generations. 


\section{DATA AND METHOD}

The Data used in this study is drawn from two related studies within the National Longitudinal Surveys (NLS) series designed by the U.S Department of Labor. The first cohort is taken from the National Longitudinal Survey of Youth 1979. This group is representative of United States residents who were born between the years 1957 and 1964. The study was conducted annually starting in 1979 and captures a longitudinal view of general young adult experiences including schooling, entering the labor market, marriage, starting families, and frequency of substance use.

In order to study the desistance processes of illegal substance use and abuse, 344 women were selected from this cohort who admitted to having used marijuana in the past 12 months at the time they were interviewed in 1984 and who also participated in the 1992 survey. In order to study the effect of getting married, the women were also only selected if they had either married in the span of the 8 years or had never married. Because the respondents were mostly in their late teens or early twenties in the first wave, only a small number had become divorced, remarried or widowed over the course of the 8 years. These respondents were too few to draw any concrete conclusions about the effect of these marital statuses. Therefore, those who had divorced, separated, were widowed, or who had entered into a second marriage were excluded from the sample to be studied. The average age of this group was 22.1 years at the interview date in 1984 . The women were asked again about any marijuana use in the previous twelve months in 
the 1992 survey, an eight year span that generally covered the beginning and end of most of the respondent's formative 20's. The racial composition of the group selected is 13.7\% Hispanic, 33.1\% African American and 53.2\% white. The overall attrition rate for those who admitted to having used marijuana in the past 12 months in 1984 to 1992 was $22.3 \%$.

The second cohort used in this analysis is taken from the National Longitudinal Survey of Youth 1979 Children and Young Adults (NLSY79 Children and Young Adults). Begun in 1986, this survey consists of the children of the females in the original NLS79 survey. For children under the age of ten years old, the child's mother completes the assessments. However, beginning in 1994, all children age fifteen and older participated in the young adult survey every two years. The young adult survey is modeled after the original NLSY79 survey, facilitating between-generation longitudinal comparisons. Similar to the first generation, 176 females were selected from the secondgeneration cohort who admitted to having used marijuana in the past 12 months when interviewed in 2002 and who also participated in the study eight years later in 2010 and who either got married or never married in the intervening eight years. The average age of this second cohort is 19.5 when interviewed in 2002, and 27.4 at the 2010 interview. Only the eldest child of each mother from the 1979 survey was eligible for selection in the second sample to ensure that only one child per family was included. The racial composition of this group of women is $17.6 \%$ Hispanic, $18.2 \%$ African American, and $64.2 \%$ white. The attrition rate over the eight years for those who admitted to having used marijuana in the past 12 months in 2002 was $24.7 \%$. 


\section{Dependent Variable}

The outcome variable in the analysis was a dichotomous measure of desistance from marijuana-use for at least the prior 12 months at the final interview. All of the women selected in both cohorts had originally admitted to having used marijuana in the previous twelve months at the first interview date: either 1984 or 2002 . Based on their answers over their respective eight-year periods, they were placed into either a 'desister' group, in which the respondents reported no marijuana use in the past 12 months in the last survey, or a 'persister' group that consisted of those who still reported using in the past 12 months in the last survey.

Using this operationalization of desistance and persistence in drug-use, a comparison can be made between the generations on the factors that are likely to influence inclusion in either the persister or desister group at each time period. 228 $(66 \%)$ of the women in the first, or 'mother,' generation who had reported using in 1984 had desisted from marijuana use by 1992. A slightly lower number (97 or $55.1 \%$ ) of the women in the second generation reported desistance by 2010 .

\section{Independent Measures}

Marital Status

The marital status variable is also a dichotomous variable of those who started in the beginning survey year (1984 or 2002) as single and got married over the course of the eight years, or those who were single in the beginning survey year and remained single over the course of the eight years. All respondents were single, meaning unmarried, at the time that they originally reported having used marijuana in the past 12 months in the first wave of the survey. This is important because it helps to highlight 
how change in marital status, going from being single to being married, may affect desistance processes. Again, those who were divorced, separated, widowed or who had entered into second or third marriages within the eight years were removed from the sample. Approximately half $(52 \%)$ of the first generation went from being single to being married in the eight years, while only $26.7 \%$ of the second generation married. This could be a result of the second-generation sample having a lower average age than the first generation, or the result of the second-generation women generally marrying later in life.

\section{Control Variables}

I included sociodemographic control variables of race and age, as both factors have been shown to be significant in analyses of deviant behavior. Additionally, my two samples vary in composition of average age and racial structure. In cross-tabulation analysis, African Americans in the second-generation desisted at a higher rate than Hispanics or whites. Therefore, I restructured race into a dichotomous variable with $1=$ Black and $0=$ White or Hispanic. Similarly, I restructured the age variable into $1=$ over the age of 21 , and $0=$ under the age of 21 .

Four separate binary regression models were used using the firstgeneration cohort, the second-generation cohort, the combined cohorts in one model, and finally the combined cohorts with an interaction variable between marital status and the first generation $(1=$ mothers, $0=$ children $)$ to help further clarify the differences between the generations. For all three models, the outcome variable was coded as either 1 for those who desisted from use by the last period, and 0 for those who persisted in their use. 


\section{FINDINGS}

As previously noted, slightly over half (52\%) of the women in the first generation sample married over the eight-year period encompassing most of the respondent's 20's (Table 1). And an even larger proportion (66\%) desisted from marijuana-use by the eighth year. A t-test analysis indicates a significant difference between the percentage of married women in the first cohort who desisted (75\%) and single women who desisted (56\%) (Table 2). This suggests that marriage does have a significantly deterrent effect for the $1^{\text {st }}$ generation. Likewise, looking at the regression analysis for only the first generation sample, getting married does again show a significant effect on whether the women were likely to desist or persist in their use (Table 3).

In looking at the second generation, in which only $26.7 \%$ married over the same time frame, again, 55\% desisted from use (Table 1). The t-test and logistic regression analyses show mixed results in terms of the desistance effect of marriage. The t-test (Table 2) indicates that, when control variables were removed, marriage lost its

effect on this cohort. However, logistic regression shows marriage as still slightly significant for the second generation. 
Table 1.

Descriptive Statistics

\begin{tabular}{|c|c|c|c|c|c|c|c|c|c|}
\hline & \multicolumn{3}{|c|}{$\begin{array}{c}\text { 1st Generation } \\
(\mathrm{N}=344)\end{array}$} & \multicolumn{3}{|c|}{$\begin{array}{l}2^{\text {nd }} \text { Generation } \\
(N=176)\end{array}$} & \multicolumn{3}{|c|}{$\begin{array}{c}\text { Total Sample } \\
(\mathrm{N}=\mathbf{5 2 0})\end{array}$} \\
\hline & $\mathrm{N}$ & Mean & $\begin{array}{c}\text { Std. } \\
\text { Deviation }\end{array}$ & $\mathrm{N}$ & Mean & $\begin{array}{c}\text { Std. } \\
\text { Deviation }\end{array}$ & $\mathrm{N}$ & Mean & $\begin{array}{c}\text { Std. } \\
\text { Deviation }\end{array}$ \\
\hline Married & 344 & .5203 & .50031 & 176 & .2670 & .44368 & 520 & .4346 & .49618 \\
\hline Desisted & 344 & .6628 & .47345 & 176 & .5511 & .49880 & 520 & .6250 & .48459 \\
\hline $\begin{array}{c}\text { Age } \\
(1=>21)\end{array}$ & 344 & .7297 & .44479 & 176 & .3239 & .46928 & 520 & .5923 & .49188 \\
\hline $\begin{array}{c}\text { Race } \\
(1=\text { Black })\end{array}$ & 344 & .3314 & .47140 & 176 & .1818 & .38680 & 520 & .2808 & .44981 \\
\hline
\end{tabular}

Table 2.

t-Test for Equality of Means on Desistance from Marijuana Use

\begin{tabular}{|c|c|c|c|c|c|c|c|c|c|}
\hline & \multicolumn{3}{|c|}{$\begin{array}{l}\text { 1st Generation } \\
(\mathrm{N}=344)\end{array}$} & \multicolumn{3}{|c|}{$\begin{array}{c}2^{\text {nd }} \text { Generation } \\
(N=176)\end{array}$} & \multicolumn{3}{|c|}{$\begin{array}{l}\text { Total Sample } \\
(\mathbf{N}=\mathbf{5 2 0})\end{array}$} \\
\hline & Mean & $\mathrm{t}$ & $\mathrm{p}$ & Mean & $\mathrm{t}$ & $\mathrm{p}$ & Mean & $\mathrm{t}$ & $\mathrm{p}$ \\
\hline Married & .7542 & 3.802 & .000 & .6383 & 1.403 & .162 & .7301 & 4.412 & .000 \\
\hline Single & .5636 & & & .5194 & & & .5442 & & \\
\hline African-American & .5526 & -3.075 & .002 & .7188 & 2.122 & .035 & .5890 & -1.057 & .291 \\
\hline White or Hispanic & .7174 & & & .5139 & & & .6390 & & \\
\hline Age $>21$ & .6653 & .164 & .870 & .5263 & -.456 & .649 & .6396 & .828 & .408 \\
\hline Age $<21$ & .6559 & & & .5630 & & & .6038 & & \\
\hline
\end{tabular}


In the third model, the two generations were combined into one sample $(\mathrm{N}=520)$. The same independent variables were included in order to gain insight into influences on desistance with all the women, regardless of generation. However, a dichotomous 'Mother' variable was included with $1=$ a member of the first generation (or mother) cohort and $0=\mathrm{a}$ member of the second-generation cohort. The inclusion of the 'Mother' variable would measure the impact of simply being in the earlier generation on desistance. Given the changes over time in deviant behavior and gender role expectations of women described earlier and the resultant weakening of social bonds to traditional institutions, I would expect to see the inclusion of a woman in the $1^{\text {st }}$ generation to be positively associated with her desistance from marijuana use. Similarly, I would expect women in the second generation to be more likely to continue to persist in use as traditional social bonds are weakened. Marriage does show a higher significance level in its role in desistance from marijuana use for the first-generation women $(p=.005$; Table 3) than the second-generation ( $p=.055$; Table 3$)$; however, marriage continues to show significance for the second-generation. And in the overall combined sample, marriage still had a strong effect $(\mathrm{p}=.000$; Table 3$)$.

Despite the generational difference by itself having shown no effect on the desistance process, the institution of marriage specifically may show unique generational effects. Again, I hypothesized that marriage would prove a weaker predictor of desistance for the younger cohort. To test this specifically, I created an interaction term between the 'Marriage' and the 'Mother' (first generation) variables. If this interaction term proved significant, it would show, as expected, that marriage had a stronger effect on desistance for the earlier generation. However, the interaction term was not 
significant, and furthermore, when the interaction term was added to the model, marriage lost its significance for the combined cohorts (Table 3). These findings suggest that the effect of a marital bond on the desistance process has not become clearly weaker for women over subsequent generations over time.

One notable finding for future analysis was the effect of race on desistance, specifically for the second-generation cohort. My results indicate that African-American women were actually more likely to desist in the second-generation than were white or Hispanic respondents $(p=.014)$. A more detailed examination is required to determine the exact social dynamics of this inter-generational difference, but it is a noteworthy topic to explore further in analyses of marriage and marijuana-use. 
Table 3.

Logistic Regression

\begin{tabular}{|c|c|c|c|c|c|c|c|c|c|c|c|c|}
\hline & \multicolumn{3}{|c|}{$\begin{array}{c}\text { 1st Generation } \\
(\mathrm{N}=344)\end{array}$} & \multicolumn{3}{|c|}{$\begin{array}{c}2^{\text {nd }} \text { Generation } \\
(N=176)\end{array}$} & \multicolumn{3}{|c|}{$\begin{array}{l}\text { Total Sample } \\
\quad(520)\end{array}$} & \multicolumn{3}{|c|}{$\begin{array}{l}\text { Total Sample with } \\
\text { Interaction Term } \\
\quad(\mathrm{N}=\mathbf{5 2 0})\end{array}$} \\
\hline & $\begin{array}{c}\mathrm{B} \\
(\mathrm{SE}) \\
\end{array}$ & $\begin{array}{l}\operatorname{Exp} \\
\text { (B) }\end{array}$ & $\mathrm{p}$ & $\begin{array}{c}\mathrm{B} \\
(\mathrm{SE}) \\
\end{array}$ & $\begin{array}{l}\operatorname{Exp} \\
(\mathrm{B})\end{array}$ & $\mathrm{p}$ & $\begin{array}{c}\mathrm{B} \\
(\mathrm{SE}) \\
\end{array}$ & $\begin{array}{l}\text { Exp } \\
(\mathrm{B})\end{array}$ & $\mathrm{p}$ & $\begin{array}{c}\mathrm{B} \\
(\mathrm{SE}) \\
\end{array}$ & $\begin{array}{l}\text { Exp } \\
(\mathrm{B}) \\
\end{array}$ & $\mathrm{p}$ \\
\hline $\begin{array}{l}\text { Married } \\
\quad(1= \\
\text { Married; } 0 \\
=\text { Single })\end{array}$ & $\begin{array}{l}.734 \\
(.263)\end{array}$ & 2.083 & .005 & $\begin{array}{c}.705 \\
(.368)\end{array}$ & 2.024 & .055 & $\begin{array}{c}.781 \\
(.212)\end{array}$ & 2.183 & .000 & $\begin{array}{l}.513 \\
(.355)\end{array}$ & 1.670 & .148 \\
\hline $\begin{array}{c}\text { Race } \\
(1=\text { Black; } \\
0=\text { White } \\
\text { or } \\
\text { Hispanic })\end{array}$ & $\begin{array}{l}-.312 \\
(.274)\end{array}$ & .732 & .256 & $\begin{array}{l}1.087 \\
(.444)\end{array}$ & 2.966 & .014 & $\begin{array}{l}.076 \\
(.226)\end{array}$ & 1.079 & .736 & $\begin{array}{l}.108 \\
(.229)\end{array}$ & 1.115 & .636 \\
\hline $\begin{array}{c}\text { Age } \\
(1=>21 ; \\
0=<21)\end{array}$ & $\begin{array}{l}.133 \\
(.265)\end{array}$ & 1.142 & .616 & $\begin{array}{l}-.391 \\
(.344)\end{array}$ & .676 & .256 & $\begin{array}{l}-.062 \\
(.208)\end{array}$ & .940 & .765 & $\begin{array}{l}-.048 \\
(.209)\end{array}$ & .953 & .819 \\
\hline Mother & & & & & & & $\begin{array}{l}.301 \\
(.218)\end{array}$ & 1.351 & .168 & $\begin{array}{l}.164 \\
(.263)\end{array}$ & 1.178 & .533 \\
\hline $\begin{array}{l}\text { Mother by } \\
\text { Married } \\
\text { (Interaction } \\
\text { Term) }\end{array}$ & & & & . & & & & & & $\begin{array}{l}.399 \\
(.429)\end{array}$ & 1.490 & .353 \\
\hline Constant & $\begin{array}{r}.332 \\
(.283) \\
\end{array}$ & 1.393 & .241 & $\begin{array}{l}-.038 \\
(.213) \\
\end{array}$ & .963 & .859 & $\begin{array}{l}.012 \\
(.180) \\
\end{array}$ & 1.012 & .947 & $\begin{array}{c}.067 \\
(.190) \\
\end{array}$ & 1.070 & .723 \\
\hline $\begin{array}{c}\text { Nagelkerke } \\
\mathrm{R}^{2}\end{array}$ & & .061 & & & .067 & & & .055 & & & .058 & \\
\hline
\end{tabular}




\section{DISCUSSION}

Social control theory stresses the bonds that an individual forms with certain institutions and how the strength of these bonds influence deviant behavior, or more specifically, the lack of deviant behavior. Sampson and Laub's age-graded theory of informal social control adds a more longitudinal approach in emphasizing how an individual experiences various age-related transitions in life over time, and how these transitions play a role in altering or continuing behavior. They found that life-transitions such as getting married, beginning a career and the birth of a child play a significant role in modifying behavior and life-trajectories. Attachments to such informal institutions are associated with bringing an individual with a history of deviant or criminal conduct in line with more conventional behavior. Furthermore, these crucial transition points are traditionally most likely to occur in young adulthood. However, as Elder noted, these experiences are also subject to social historical change: what one generation experiences as typical for young adulthood, the norms of young adulthood for the next generation may have evolved.

In Sampson and Laub's work, entering into marriage was found to be one

of the strongest informal control factors in desistance from criminal and deviant behavior. Yet the institution of marriage has experienced well-documented changes over the last century with the divorce rate rising, individuals marrying later in life, greater likelihood of cohabitation outside of marriage and increased gender parity in the domestic-work life 
balance between spouses. With these historical changes in mind, what many analyses of age-graded life course theory exclude is how gender may affect the formation of social bonds, and subsequently, how social bonds affect desistance from deviance along gendered lines. The age-graded theory of informal social control was created necessarily using an all-male sample from over half a century ago, but with the historical changes in marriage and gender roles, it is relevant to analyze the female experience over time as well. Therefore, given the significance placed on marriage in theories of informal social control, the historical changes in marriage, and the general lack of a gendered, longitudinal approach to the theory, the goal of this study was to examine the differential affect of marriage on desistance from drug-use in two generations of women.

Despite my hypothesis, however, that the effect of the marital bond on the desistance process would grow weaker for women over time, I found no strong evidence that this was the case. Using binomial logistic regression on the separate samples, the outcome here does indicate that marriage may be getting weaker for the second generation, but its effect is still significant. A similar result is observed in the combinedsample model in which marriage continues to be significant, but when the interaction term is included in the model between marriage and the first generation, significance is lost, indicating again that the marital bond does not play a stronger role on desistance for the first generation as hypothesized.

The results indicate an interesting dynamic in the changing interaction patterns between gender, marriage, race, marijuana use, and desistance. It seems that whatever the exact combination of social forces that has resulted in a higher rate of female deviancy, or at least arrests, over the past several decades, a weakening marital 
bond has not been one of them. This is not surprising given that changes in the institution of marriage have not been uniformly negative, especially for women, and these changes may have actually increased the strength of the marital bond. Despite social alarm and heated political debate over falling marriage rates and rising divorce rates, marriage is not necessarily becoming a weaker institution; it is possible that its defining characteristics are just evolving. Women have particularly benefited from what economists Betsey Stevenson and Justin Wolfers have posited as the biggest trends that have altered family life and marriage: the rise of the women's liberation movement, the sexual revolution, the Supreme Court's granting of marriage as a fundamental right, the elimination of faultbased divorce, later average age of marriage, increased female education, and the sharp rise in women's labor force participation (Stevenson and Wolfers, 2007). It is possible that as women increasingly gain autonomy and see themselves as equals in marriage relationships, their stake in, and therefore their attachment to, the institution increases.

To further clarify and build on these outcomes, it will be necessary in the future to look more closely at the individual variables involved. The marriage variable I created was only a two-part measurement: stayed single, or got married. In the future, it would be useful, again given different divorce rates, to include the effects that getting divorced may have had on desistance as well. And given Sampson and Laub's emphasis on not just marriage, but the quality of marriage, a logical next step would be to investigate the exact mechanisms involved in marriage length and quality. Similarly, relationship quality, the presence of children, and employment all have been shown to have a unique effect for women on desistance (Thompson and Petrovic, 2009). 
Therefore, a more detailed analysis of this hypothesis would next include all of those variables in a generational comparison.

Also, I was somewhat limited with the current dataset in the selection of the generations for comparison. The first generation was entering young adulthood in the late 1980's, arguably after the effects of the women's liberation movement and any major changes to marriage and the family may have taken place. Therefore, I was comparing two post-baby boomer generations with relatively similar values and experiences and may not have captured all of the between-generation effects that may have been present in a more widely separated generational comparison. However, very few longitudinal studies follow females in the baby-boomer generation over time, and even fewer analyze deviance and desistance. The National Longitudinal Survey of Youth Series was unique in that it allowed for me to measure change by following and comparing two generations over time on similar variables. The survey is still currently ongoing and should yield even greater opportunities for generational analysis in the future as the second generation matures and has children of their own.

Future studies similar to this one would benefit also in expanding the deviance measure. Only marijuana-use was used here, but different meanings are attached to different operationalizations of deviance. For example marijuana, while still illegal and not sanctioned by conventional society, is still a relatively innocuous drug and desisting from marijuana may involve completely different mechanisms than desisting from harder drugs like cocaine or heroine and likely involve entirely different social networks. It would be informative therefore, to use a range of deviance measures as well as a comparison of the 'seriousness' of each deviance measure, therefore also examining 
the social meaning attached to specific behaviors and the variance in desistance processes.

The findings in this analysis, which indicate that the marital bond has not become substantially weaker in its effect on desistance over two generations, initiate more questions than they answer. Particularly, how is marriage affecting these two generations differently? And how is marriage evolving in a way that may indicate it still has an effect on desistance for women despite the rising rates of female criminal involvement? Future research in this area will need to expand on both measures of social dynamic and change, including more variables that are likely to affect women including employment and the presence of children. It will also benefit from becoming more nuanced in defining measures of deviance and desistance. However, despite the questions still to be answered, the present analysis contributes to the study of, and hopefully initiates further interest in, how the interconnectivity of macro-level historical trends, generational values, and micro-level individual processes combine to create change. 


\section{REFERENCES}

Adler, Freda. 1975. Sisters in Crime: The Rise of the New Female Criminal New York: McGraw-Hill Book Co.

Anderson, Elijah. 1978. A Place on the Corner. Chicago: University of Chicago Press.

Bengtson, Vern L., Timothy J. Biblarz, and Robert E.L. Roberts. 2002. How Families Still Matter: A Longitudinal Study of Youth in Two Generations. Cambridge, UK: Cambridge University Press.

Bennett, Trevor, Katy Holloway, and David P. Farrington. 2008. The Statistical Association Between Drug Misuse and Crime: A Meta Analysis. Aggression and Violent Behavior 13: 107-118.

Blokland, Arjan A.J., and Paul Nieuwbeerta. 2005. The Effects of Life Circumstances on Longitudinal Trajectories of Offending. Criminology 43:1203-1240.

Blumstein, Alfred, Jacqueline Cohen and David P. Farrington. 1988. Criminal Career Research: Its Value for Criminology. Criminology 26: 1-35.

Brown, Susan L., and Alan Booth. 1996. Cohabitation vs. Marriage: A Comparison of Relationship Quality. Journal of Marriage and Family 58: 668-678.

Cernkovich, Stephen A., and Peggy C. Giordano. 2008. A Comparative Analysis of Male and Female Delinquency. The Sociological Quarterly 20:131-145.

Chen, Kevin, and Denise B. Kandel. 1995. The Natural History of Drug Use from Adolescence to the Mid-Thirties in a General Population Sample. American Journal of Public Health 85:41-47.

Cherlin, Andrew J. 2004. The Deinstitutionalization of American Marriage. Journal of Marriage and Family 66: 848-861.

Chesney-Lind, Meda. 1989. Girls' Crime and Woman's Place: Toward a Feminist Model of Female Delinquency. Crime \& Delinquency 35:5-29.

Chesney-Lind, Meda. 2006. Patriarchy, Crime, and Justice: Feminist Criminology in an Era of Backlash. Feminist Criminology 1:6-26. 
Duncan, Greg J., Bessie Wilkerson, and Paula England. 2006. Cleaning Up Their Act: The Effects of Marriage and Cohabitation on Licit and Illicit Drug Use. Demography 43: 691-710.

Elder, Glen H. 1975. Age Differentiation and the Life Course. Annual Review of Sociology 1:165-190.

Elder, Glen H. 1985. Perspectives on the Life Course. In Life Course Dynamics: Trajectories and Transitions, 1968-1980, ed. Glen H. Elder. Ithaca: Cornell University Press.

Elder, Glen H. 1998. The Life Course as Developmental Theory. Child Development. 69:1-12.

Farrington, David P. 1986. Age and Crime. In Crime and Justice: An Annual Review of Research, ed. Michael Tonry and Norval Morris. Chicago: University of Chicago Press.

Giordano, Peggy C. 1978. Girls, Guys, and Gangs: The Changing Social Context of Female Delinquency. The Journal of Criminal Law and Criminology 69: 126-132.

Giordano, Peggy C. and Stephen A. Cernkovich. 1979. On Complicating the Relationship Between Liberation and Delinquency. Social Problems 26: 467-481.

Giordano, Peggy C., Stephen A. Cernkovich, and Donna D. Holland. 2003. Changes in Friendship Relations Over the Life Course: Implications for Desistance from Crime. Criminology 41:293-327.

Giordano, Peggy C., Stephen A. Cernkovich, and Jennifer L. Rudolph. 2002. Gender, Crime, and Desistance: Toward a Theory of Cognitive Transformation. American Journal of Sociology 107:990-1064.

Glueck, Sheldon, and Eleanor Glueck. 1950. Unraveling Juvenile Delinquency. Cambridge, MA: Harvard University Press.

Gottfredson, Michael R. and Travis Hirschi. 1990. A General Theory of Crime. Stanford, CA: Stanford University Press.

Hirschi, Travis. 1969. Causes of Delinquency. Berkeley and Los Angeles: University of California Press.

Horney, Julie, D. Wayne Osgood, and Ineke H. Marshall. 1995. Criminal Careers in the Short-term: Intra-individual Variability in Crime and its Relation to Local Life Circumstances. American Sociological Review 60:655-73. 
Jessor, Richard, John E. Donovan, and Frances M. Costa. 1991. Beyond Adolescence: Problem Behavior and Young Adult Development. Cambridge, MA: Cambridge University Press.

Keyes, Corey L., and Mary Beth Waterman. 2003. Dimensions of Well-Being and Mental Health in Adulthood. In Well-being: Positive Development Across the Life-Course. Crosscurrents in Contemporary Psychology, ed. Marc H. Bornstein, Lucy Davidson, Corey Keyes, and Kristin Moore. Mahway, NJ: Lawrence Erlbaum Associates Publishers.

Kreider, Rose M. and Travis Simmons. 2003. Marital Status: 2000. United States Census Bureau. October 2003. http://www.census.gov/prod/2003pubs/c2kbr-30.pdf

Labouvie, Erich. 1996. Maturing Out of Substance Use: Selection and Self-Correction. Journal of Drug Issues 26:457-476.

Laub, John H., Daniel S. Nagin, and Robert J. Sampson. 1998. Trajectories of Change in Criminal Offending: Good Marriages and the Desistance Process, American Sociological Review 63:225-38.

Laub, John H., and Robert J. Sampson. 2001. Understanding Desistance from Crime. Crime and Justice 28:1-69

Levinson, David. (Ed.). 2002. Encyclopedia of Crime and Punishment. Vol.1, pp.10091010. Thousand Oaks, CA: Sage Publications, Inc.

Li, Spencer D., and Doris L. MacKenzie. 2003. The Gendered Effects of Adult Social Bonds on the Criminal Activities of Probationers. Criminal Justice Review 28:278-298.

Maume, Michael O., Graham C. Ousey, and Kevin Beaver. 2005. Cutting the Grass: A Reexamination of the Link Between Marital Attachment, Delinquent Peers and Desistance from Marijuana Use. Journal of Qualitative Criminology 21: 27-53.

Menard, Scott, Sharon Mihalic and David Huizinga. 2001. Drugs and Crime Revisited. Justice Quarterly 18: 269-299.

Moore, Lisa D. and Elkavich, Amy. 2008. Who's Using and Who's Doing Time: Incarceration, the War on Drugs, and Public Health. American Journal of Public Health 98: 782-786. 
Newcomb, Michael D., Elisha R. Galaif, and Jennifer V. Carmona. 2001. The DrugCrime Nexus in a Community Sample of Adults. Psychology of Addictive Behaviors 15: 185-193.

Nguyen, Holly and Peter Reuter. 2012. How Risky is Marijuana Possession? Considering the Role of Age, Race, and Gender. Crime and Delinquency 58: 879-910.

Nielsen, Amie L. 1999. Testing Sampson and Laub's Life Course Theory: Age, Race/Ethnicity, and Drunkenness. Deviant Behavior 20:129-151.

Nurco, David N., Timothy W. Kinlock, and Thomas E. Hanlon. 1991. The Drugs-Crime Connection. In The American Drug Scene: An Anthology, ed. James A. Inciardi and Karen McElrath. Los Angeles: Roxbury Publishing Company.

Osgood D. Wayne, Janet K. Wilson, Patrick M. O’Malley, Jerald G. Bachman, and Lloyd D. Johnston. 1996. Routine Activities and Individual Deviant Behavior. American Sociological Review 61: 635-655.

Parsons, Talcott. 1942. Age and Sex in the Social Structure of the United States. American Sociological Review 7:604-616.

Rhule-Louie, Dana M., and Robert J. McMahon. 2007. Problem Behavior and Romantic Relationships: Assortative Mating, Behavior Contagion, and Desistance. Clinical Child and Family Psychology Review 10:53-100.

Saluter, Arlene F. and Terry A. Lugaila. 1998. Marital Status and Living Arrangements: March 1996. United States Census Bureau. March 1998, http://www.census.gov/prod/3/98pubs/p20-496.pdf

Sampson, Robert J., and John H. Laub. 1993. Crime in the Making: Pathways and Turning Points Through Life. Cambridge, MA: Harvard University Press.

Sampson, Robert J., and John H. Laub. 1994. Urban Poverty and the Family Context of Delinquency: A New Look at Structure and Process in a Classic Study. Child Development 65: 523-540.

Simon, Rita J. 1975. Women and Crime Lexington Mass.: Lexington Books.

Stacey, Judith. 1998. Brave New Families: Stories of Domestic Upheaval in LateTwentieth-Century America Berkeley: University of California Press.

Steffensmeier, Darrell J. 1980. Sex Differences in Patterns of Adult Crime, 1965-77: A Review and Assessment. Social Forces 58:1080-1109. 
Thompson, Melissa, and Milena Petrovic. 2009. Gendered Transitions: Within-Person Changes in Employment, Family, and Illicit Drug-Use. Journal of Research in Crime and Delinquency 46:377-408.

Stevenson, Betsey, and Justin Wolfers. 2007. Marriages and Divorce: Changes and their Driving Forces. Journal of Economic Perspectives 21:27-52.

Uggen, Christopher, and Candace Kruttschnitt. 1998. Crime in the Breaking: Gender Differences in Desistance. Law and Society Review 32:339-365

Warr, Mark. 1998. Life-course Transitions and Desistance from Crime. Criminology 36:183-216.

Weis, Joseph G. 1976. Liberation and Crime: The Invention of the New Female Criminal. Crime and Social Justice 6:17-27. 


\section{CURRICULUM VITA}

NAME: Rachel Jeannette Coonce

ADDRESS: 1601 Spring Drive, \#12

Louisville, KY 40205

DOB: $\quad$ Cookeville, Tennessee - October 23, 1983

EDUCATION

\& TRAINING: $\quad$ B.A., History

Centre College

2002-2006

Field Interviewer

National Health \& Alcohol Study

Westat

2012-2013

Analyst

Department of Casualty, Fort Knox

2010-2011

Graduate Teaching Assistant

University of Louisville, Sociology

2009-2010

Americorps Volunteer

Project Power

Asheville, NC

2006-2007 